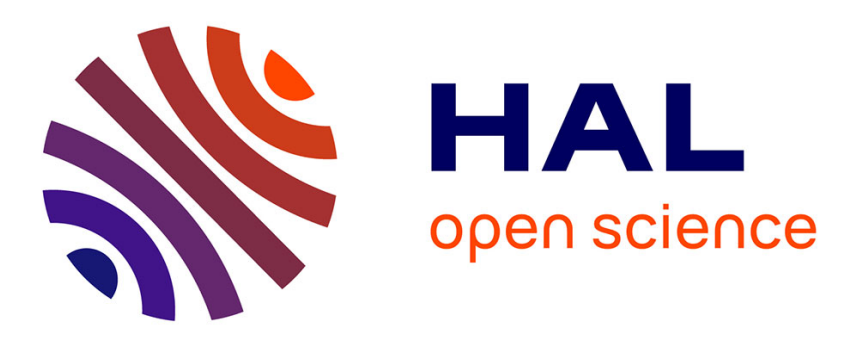

\title{
Assessing bone transformation in late Miocene and Plio-Pleistocene deposits of Kenya and South Africa
}

Julie Aufort, Dominique Gommery, Christel Gervais, Loïc Segalen, Nathalie Labourdette, Cristina Coelho-Diogo, Etienne Balan

\section{- To cite this version:}

Julie Aufort, Dominique Gommery, Christel Gervais, Loïc Segalen, Nathalie Labourdette, et al.. Assessing bone transformation in late Miocene and Plio-Pleistocene deposits of Kenya and South Africa. Archaeometry, 2019, 61 (5), pp.1129-1143. 10.1111/arcm.12471 . hal-02097000

\section{HAL Id: hal-02097000 https: / hal.sorbonne-universite.fr/hal-02097000}

Submitted on 11 Apr 2019

HAL is a multi-disciplinary open access archive for the deposit and dissemination of scientific research documents, whether they are published or not. The documents may come from teaching and research institutions in France or abroad, or from public or private research centers.
L'archive ouverte pluridisciplinaire HAL, est destinée au dépôt et à la diffusion de documents scientifiques de niveau recherche, publiés ou non, émanant des établissements d'enseignement et de recherche français ou étrangers, des laboratoires publics ou privés. 


\section{Assessing bone transformation in late Miocene and Plio-Pleistocene deposits of Kenya and South Africa}

Julie AUFORT ${ }^{1, *}$, Dominique GOMMERY², Christel GERVAIS ${ }^{3}$, Loïc SEGALEN ${ }^{4}$, Nathalie LABOURDETTE $^{4}$, Cristina COELHO-DIOGO ${ }^{5}$, Etienne BALAN $^{1}$

${ }^{1}$ Sorbonne Université, CNRS, IRD, MNHN, Institut de Minéralogie, de Physique des Matériaux et de Cosmochimie, IMPMC, UMR 7590, F-75005, Paris, France

${ }^{2}$ UMR 7207-CR2P (Centre de Recherche sur la Paléobiodiversité et les Paléoenvironnements), CNRS-MNHNSU, Sorbonne Université, Campus Pierre et Marie Curie, T.46-56, E.5, case 104, 4 Place Jussieu, 75252 Paris cedex 05, France.

${ }^{3}$ Sorbonne Université, Collège de France, Laboratoire de Chimie de la Matière Condensée de Paris, LCMCP, UMR 7574, F-75005, Paris, France

${ }^{4}$ Sorbonne Université, CNRS-INSU, Institut des Sciences de la Terre de Paris, ISTEP, UMR 7193, F-75005, Paris, France

${ }^{5}$ Sorbonne Université, Institut des Matériaux de Paris Centre, IMPC, FR2482, F-75005, Paris, France

Corresponding author : Julie Aufort, IMPMC, case 115, 4 place Jussieu, 75005 Paris, France

Email: julie.aufort@upmc.fr Phone: 00.33.1.44.27.42.27 Fax: 00.33.1.44.27.37.85

Keywords : bone diagenesis, ATR-FTIR spectroscopy, secondary apatite, preservation

\section{Abstract}

Bone reactivity offers a potential way to record local physical-chemical conditions prevailing in fossilisation environments and archaeological sites. In the present study, a series of fossil bone samples from the karstic environments of the Bolt's Farm cave system (Cradle of Humankind, South Africa) and from fluvio-lacustrine environments of the Tugen Hills (Gregory Rift, Kenya) is analysed. The chemical composition and infrared and NMR spectroscopic properties of fossil samples point to a transformation of the biogenic apatite and formation of secondary apatite. Depending on the sample, the secondary apatite corresponds to a carbonate-bearing hydroxy- or fluor-apatite. The maximum fraction of secondary apatite is close to $60 \%$, coinciding with previous observations in experimental alteration of bone in aqueous solutions and suggesting that a fraction of pristine biological apatite is likely to be preserved. The present results also suggest that the acetic acid treatment of fossil samples moderately increases their average crystallinity but may dissolve carbonate-rich domains of secondary apatite.

\section{Introduction}


Vertebrate bones are a major part of archaeological and paleontological records. Although the overall shape inherited from the living animal can be preserved, significant modifications affect the chemical composition as well as the microscopic and mesoscopic structure of bone (Trueman and Martill 2002; Hedges 2002). The apatitic fraction of fossil bone generally exhibits an overall decrease in carbonate content, enrichment in fluorine and incorporation of trace elements as well as an increase in crystallinity parameters (e.g. Keenan 2016). Accordingly, fossil bioapatite differs from the nanocrystalline carbonate-bearing hydroxylapatite corresponding to the main inorganic component of bone (Pasteris et al. 2008). Overall, fossil bones tend to display a transformation of the original bioapatite towards a carbonated fluorapatite (Kolodny et al. 1996). The organic fraction of bone also experiences in most cases a rapid degradation and is rarely preserved (Bocherens et al. 1997).

Despite its higher sensitivity to diagenetic transformation, the chemical and isotopic composition of fossil bones can complement the analyses performed on more resistant fossil enamel samples. When preserved in the fossil record, the stable isotope composition of biogenic apatite, and particularly the stable isotope composition $\left(\delta^{13} \mathrm{C}, \delta^{18} \mathrm{O}\right)$ of structural carbonate groups, provides important information on past climates, past environments, dietary preferences and habitat of vertebrates (e.g. Kohn and Cerling 2002). On the other hand, heavily transformed fossil bones may also serve as probes of local diagenetic conditions because the uptake of trace elements depends on the physical-chemical parameters prevailing during the diagenetic recrystallization of apatite (e.g. Kohn and Law 2006, Trueman et al. 2006).

As a matter of fact, the depositional environment plays an important role in the transformation of fossil bones. Nielsen-Marsh and Hedges (2000) reported that site hydrology and characteristics of the burial environment strongly affect diagenetic pathways in bone. Several studies have focused on the diagenesis of fossils from fluvial and marine settings (Pfretzschner 2004, Tütken et al. 2008) and from harsh weathering environments (Tuross et al. 1989, Trueman et al. 2004) to identify parameters controlling the early diagenesis of bones and teeth. Fossilisation in karstic environment is often considered to lead to better preservation. For example, Michel et al. (1995) reported only minor structural and chemical changes in fossil tooth enamel from the Lazaret prehistoric Cave and most fossil bones from karstic caves in Israel did not show transformation into carbonated fluorapatite (Weiner et al. 2002). Local variations in environmental conditions can also lead to different diagenetic pathways within one site (e.g. Stiner 2001, Bocherens et al. 2008). 
The extent of fluoridation is usually used as a marker of diagenetic transformation of bone due to the easy formation of secondary fluorapatite. However, the availability of fluorine in the environment is variable in different fossilisation contexts (e.g. Parker et al. 1974), whereas the formation of secondary hydroxyapatite is less easily detected (Aufort et al., 2019). In this work, we analyse a series of Plio-Pleistocene fossil bones from karstic environments of the Bolt's Farm cave system in the Cradle of Humankind, South Africa and from late Miocene fluvio-lacustrine environments of the Tugen Hills in the Gregory Rift, Kenya. The results further document the links between atomic scale transformation of bone and fossilisation context and suggest that a primary biogenic apatite fraction is preserved even in heavily transformed samples.

\section{Materials and Methods}

\subsection{Samples and fossilisation context}

The fossil material consists of fragments of mammal bones from the Bolt's Farm cave system (BFCS), aka Bolt's Farm, located on the south-western edge of the UNESCO Cradle of Humankind World Heritage Site, South Africa. Bolt's Farm cave system is not a single deposit but actually corresponds to an area of more than 30 fossiliferous cave infill deposits, related to a vast ancient but interconnected karstic system (Gommery et al. 2012). Main mammals found at Bolt's Farm include non-human primates such as Parapapio and Cercopithecoides, large felids such as Dinofelis and Panthera, as well as suids and bovids, but also a rich microfauna (mainly represented by rodents), and are described in details in Gommery et al. (2016) and Pickford and Gommery (2016). Bone fragments investigated in this study come from selected localities in Bolt's Farm: Waypoint 160 (WP), Brad Pit A and B (BPA, BPB), Aves Cave I (AC), Milo A (MA), Milo B (MB) and Bridge Cave (BC). These localities differ in age, e.g. Waypoint 160 was dated between 4.5 and $4 \mathrm{Ma}$ with biochronology and corresponds to the oldest fossiliferous deposit of the Cradle of Humankind (Sénégas and Avery 1998) while AC was dated, also with biochronology, between 3 and 2.5 Ma (Pickford and Gommery 2016). Selected fossil bone samples are described in Table 1 and either come from indurated calcitic breccia (B) or decalcified breccia (DB). Note that, for this study, all fossil bones were directly sampled without chemical dissolution of the breccia.

Two fossil bone samples from the Lukeino formation (6.2-5.7 Ma, Sawada et al. 2002; Roche et al. 2010; 2013) located along the Tugen Hills in the Gregory Rift Valley, Kenya were added to the series. 
A metapodial bone of modern ox, TH1, collected on the shores of the Bogoria Lake (Kenya) and a natural sample of carbonated fluorapatite (C-Fap) originating from the sedimentary deposit of Taiba (Senegal) were used as references (Aufort et al. 2019).

\subsection{Analytical techniques}

A rotary drill equipped with a diamond-tipped burr was used to collect bone powders from cortical bone fragments. Powders were then finely ground with an agate mortar and pestle for 15 minutes, producing grain sizes of less than $50 \mu \mathrm{m}$. Prior to chemical analyses, fossil bone powders were treated with $0.1 \mathrm{M}$ acetic acid for 30 minutes to remove diagenetic calcite and then rinsed 6 times with deionized water and dried at $60^{\circ} \mathrm{C}$.

Fluorine content and $\mathrm{Ca} / \mathrm{P}$ ratios are reported in Table 1 . For each analysis, $100 \mathrm{mg}$ of sample was dissolved in a $30 \%$ nitric acid solution for $1 \mathrm{~h}$ at $80^{\circ} \mathrm{C}$ following the protocol previously used by Maurer et al. (2011). Fluorine content was measured using a fluoride ion selective electrode (Mettler Toledo), Ca was measured by energy dispersive X-ray fluorescence (Niton XL3t Thermo Fischer scientific) and phosphorus by spectrophotometry (Milton Roy Spectronic 301 spectrometer). The estimated analytical error based on the analysis of a certified reference material (bone ash SRM 1400) is about $5 \%$.

Attenuated total reflectance Fourier transform infrared (ATR-FTIR) spectra were recorded using a Quest ATR device and a Nicolet 6700 FTIR spectrometer. Pure powder samples were packed at the surface of the ATR internal reflection element (IRE) and two different spectra were recorded for each sample, using either a diamond or a Ge ATR IRE, between 400 and $4000 \mathrm{~cm}^{-1}$ by averaging 200 scans with a resolution of $1 \mathrm{~cm}^{-1}$. The use of a diamond ATR IRE allows the detection of relatively weak bands, such as those related to carbonate impurities. In comparison, Ge ATR is less sensitive but provides a better insight into the intrinsic properties of the sample (Aufort et al. 2016). All ATR spectra are reported in absorbance units $A=\log \left(I_{0} / I_{R}\right)$ where $I_{0}$ and $I_{R}$ are the intensities of the incident and reflected light, respectively.

Single-pulse ${ }^{19} \mathrm{~F}$ magic angle spinning (MAS) NMR experiments were performed on an Avance 700 Bruker spectrometer (16.3T) operating at $658.93 \mathrm{MHz}$ using a $4 \mathrm{~mm}$ rotor at a 14 $\mathrm{kHz}$ spinning frequency.

\section{Results}

\subsection{Chemical composition of fossil bones}


Compared to modern bone, all fossil bones are enriched in fluorine. The fluorine content of most Bolt's Farm fossil bones range from 0.5 to 1.4 wt.\%, apart from two more fluorinated samples, AC-DB-L and MA-DB-03N, containing 1.8 and 2.4 wt.\% F respectively (Table 1). In contrast, fossil bones from the Tugen Hills, TH33 and TH32, display higher fluorine content, 2.8 and $2.9 \mathrm{wt} . \%$ F respectively.

The $\mathrm{Ca} / \mathrm{P}$ mass ratios range from 2.11 to 2.44 in all fossil samples, higher than the 2.02 value found for modern bone, as is typically observed in fossil compared to modern bioapatites (e.g. Reiche et al. 2003, Yi et al. 2014). These values are overall lower than those previously reported in Quaternary archaeological bones from Lazaret Cave (between 2.38 and 2.80; Michel et al. 1996) potentially reflecting differences in sample treatments prior to chemical analysis.

\subsection{Infrared spectroscopic study of fossil bone samples}

\subsubsection{ATR-FTIR spectra of fossil samples}

Both diamond and Ge ATR-FTIR spectra of fossil bones (Figure 1) display the characteristic absorption bands ascribed to the internal vibrations of apatite phosphate groups, and to the structural carbonate impurities located at the A and B sites (channel and phosphate sites, respectively) (e.g. LeGeros et al. 1969; Elliott 2002).

Intense bands observed between 550 and $600 \mathrm{~cm}^{-1}$ and between 1010 and $1090 \mathrm{~cm}^{-1}$ in the ATR-FTIR spectra of recent and fossil bones are related to the $v_{4} \mathrm{PO}_{4}$ bending and $v_{3} \mathrm{PO}_{4}$ stretching modes of the apatite phosphate groups, respectively. Amide bands related to the collagen matrix (Lebon et al. 2016) are not visible in the ATR-FTIR spectra of fossil bones, attesting to the degradation of the bone organic fraction. Compared to that of modern bone, diamond ATR-FTIR spectra of Bolt's Farm fossil bones containing less than $1.2 \mathrm{wt}$ \% $\%$ F display two additional bands at 630 and $3572 \mathrm{~cm}^{-1}$ related to the $\mathrm{OH}$ bending and stretching modes respectively (Figure 1, Figure S1). These bands are no longer visible in fossil bones from Bolt's Farm and the Tugen Hills with higher fluorine contents, apart from one sample, AC-DB-L (1.8 wt.\% F).

Most Bolt's Farm fossils collected from the indurated breccia contained calcite as attested by the presence of the $\mathrm{v}_{4} \mathrm{CO}_{3}$ band at $713 \mathrm{~cm}^{-1}$ (Figure $\mathrm{S} 2$ ). Its absence in the spectrum of acetic acid treated samples confirms the removal of diagenetic calcite from these samples (Figure S2). As the $v_{2} \mathrm{CO}_{3}$ and $v_{3} \mathrm{CO}_{3}$ bands of calcite overlap with those of structural carbonates in apatite, the acetic acid treatment should facilitate the analysis of the environment 
of structural carbonates in fossil samples. Although the ATR-FTIR spectra of most fossil bones from decalcified breccia did not reveal the presence of calcite, selected samples from decalcified breccia were also treated with acetic acid to assess the effect of the treatment on the apatite structure. A systematic reduction of the relative intensity of $v_{2}$ and $v_{3} \mathrm{CO}_{3}$ bands is observed after acetic acid treatment on diamond ATR-FTIR spectra after normalization based on the $v_{4} \mathrm{PO}_{4}$ band (Figure S3), whether the initial sample contained calcite or not. On calcitebearing samples, the calcite removal makes the characteristic signals of structural carbonate groups visible on the spectra.

3.2.2. Atomic-scale order and sample micro-structure probed by ATR-FTIR phosphate bands

The width of the $v_{4} \mathrm{PO}_{4}$ bands is commonly used as a probe of structural order through the measurement of the Infrared Splitting Factor (IRSF; Weiner and Bar-Yosef 1990). IRSF values measured on Ge ATR-FTIR spectra of Bolt's Farm fossils range from 3.93 to 5.72 and are overall higher than the 3.64 value found for modern bone (Table 1). IRSF values for fossil bones from the Tugen Hills, 4.24 and 4.69, fall in the range of values found in Bolt's Farm fossils. The width of the $v_{4} \mathrm{PO}_{4}$ bands is reduced after acetic acid treatment (Figure 2a), which leads to a systematic increase in IRSF in all fossil bones treated, whether the sample originally contained calcite or not (Table 1, Figure 2b).

The line shape and width of strong bands in infrared spectra are not only related to the atomic-scale structure of the samples but also depend on parameters such as porosity, grain size and shape of particles due to long-range electrostatic interactions within and between particles (Aufort et al., 2016). In contrast the position and line shape of weaker bands, such as the band at $\sim 960 \mathrm{~cm}^{-1}$ related to the $v_{1} \mathrm{PO}_{4}$ stretching mode, are less affected by these effects. Compared with the $v_{4} \mathrm{PO}_{4}$ band, the weaker $v_{1} \mathrm{PO}_{4}$ band is thus expected to provide a complementary meaningful insight into the atomic-scale properties of the sample (Balan et al. 2011, Aufort et al. 2016, 2018). Its position has been shown to be well correlated to apatite crystallinity in archaeological heated bones (Lebon et al. 2014).

The $v_{1} \mathrm{PO}_{4} \mathrm{Ge}$ ATR-FTIR band is located at $~ 960 \mathrm{~cm}^{-1}$ in modern ox bone TH1 and at $\sim 966 \mathrm{~cm}^{-1}$ in the carbonated fluorapatite (C-Fap) sample. It corresponds to a broad Gaussian signal in TH1 while it displays a pronounced Lorentzian shape in C-Fap. Compared to modern bone, the $v_{1} \mathrm{PO}_{4}$ Ge ATR-FTIR band of fossil bones is asymmetric and systematically shifted towards higher frequencies (Table 1, Figure 1d, Figure S4), which is consistent with the 
incorporation of fluorine in the apatite structure. Its position correlates with the sample fluoride content (Figure 4a) and is unaffected by the acetic acid treatment. These observations are consistent with those made on artificially altered modern bones by Aufort et al. (2019) who observed the partial dissolution of biogenic apatite and precipitation of secondary apatite, in bone artificially altered in pH-buffered and fluorinated aqueous solutions. Depending on the composition of the aqueous solution, carbonated hydroxyapatite or fluorapatite was identified as the secondary phase. A quantitative analysis of ATR-FTIR bands revealed that the transformation process was incomplete with a fraction of secondary apatite limited to about $60 \%$. A similar approach was used in the present work. It consists in fitting the $v_{1} \mathrm{PO}_{4} \mathrm{Ge}$ ATRFTIR band of fossil samples by using a two-component model to fit the band shape (Table S1). The first component is a Gaussian function, whose position and width were kept fixed to that of the unaltered bone sample (TH1). Accordingly, it is expected to correspond to remnants of the biogenic material in the fossil samples. The second component, which is expected to correspond to secondary apatite, is described by a Lorentzian function whose position, relative intensity, and width are free parameters (Table S1). The fraction of secondary apatite obtained from the fits varies between 24 and $60 \%$ in Bolt's Farm fossils, while it reaches $64 \%$ in fossil bones from the Tugen Hills (Table S1). The position of the peak is mainly centred on 962.5$963.5 \mathrm{~cm}^{-1}$ in Bolt's Farm fossils apart from the two F-rich samples for which the position is higher and closer to that of sedimentary carbonated fluorapatite $\left(966.1 \mathrm{~cm}^{-1}\right)$. Regarding fossils from the Tugen Hills, a high proportion of secondary carbonated fluorapatite is consistent with their higher fluorine content. It is noteworthy that even in highly transformed bone samples, i.e. TH33 and TH32, the proportion of secondary apatite is limited to about 64\% (Table S1).

\subsubsection{Environment of structural carbonate groups inferred from the $v_{2} \mathrm{CO}_{3}$ band}

The $v_{2} \mathrm{CO}_{3}$ component of modern bone displays the usual A- and B-type components at $\sim 880 \mathrm{~cm}^{-1}$ and $\sim 872 \mathrm{~cm}^{-1}$ respectively, as well as an asymmetric tail on the low-frequency side, which corresponds to the broad band centred at $860-865 \mathrm{~cm}^{-1}$ attributed to "labile" carbonate groups in bone (Rey et al. 1989) (Figure 1c, Figure S5).

All fossil bones display an additional signal at $865 \mathrm{~cm}^{-1}$ that matches with that observed in the reference sedimentary carbonated fluorapatite. This signal is diagnostic of a clumped $\left(\mathrm{CO}_{3}{ }^{2-}, \mathrm{F}^{-}\right)$defect substituting for the phosphate group in the apatite structure and has been observed in fossil teeth from Rift Gregory in Kenya (Yi et al. 2013, 2014). 
Regarding calcite-free fossils, the apparent proportions of clumped $\left(\mathrm{CO}_{3}{ }^{2-}, \mathrm{F}^{-}\right)$defect, A-type and B-type carbonate signals are modified in the most fluorinated samples (AC-DB-L and MA-DB-03N) after acetic acid treatment (Figure S3). Together with the overall decrease in the relative intensity of the structural carbonate signals in normalized spectra, this suggests that the acetic acid treatment could have removed a fraction of carbonate-bearing secondary phases. Depending on the sample, the acid acetic acid treatment removes carbonates associated either with the clumped defect or with B-type and A-type substitutions.

\section{3. ${ }^{19}$ F Nuclear Magnetic Resonance Spectroscopy}

The ${ }^{19} \mathrm{~F}$ MAS NMR spectra of fossil bones display a main signal at - $102 \mathrm{ppm}$ ascribed to $\mathrm{F}^{-}$ions incorporated in the channel sites of the apatite structure (Figure 3). This signal is broader in Bolt's Farm fossil bone samples (FWHM of 2.12-3.69 ppm) than in the reference sedimentary carbonated fluorapatite $(1.8 \mathrm{ppm})$. The less intense signal observed in sedimentary carbonated fluorapatite at $-88 \mathrm{ppm}$ corresponds to the clumped $\left(\mathrm{CO}_{3}{ }^{2-}, \mathrm{F}^{-}\right)$defect substituting for the phosphate group in the structure of carbonated fluorapatite (Yi et al. 2013). This signal is also observed in the fossil samples. ${ }^{19} \mathrm{~F}$ MAS NMR thus confirms that fluoride is incorporated in the apatite structure, both in the channel sites and in the clumped defect to a lesser extent. The clumped defect signal is more intense in samples with higher fluorine content, i.e. MADB-03N and TH33 (with an area about 3\% that of the total area of the ${ }^{19} \mathrm{~F}$ NMR spectrum), than in BPB-DB-25 (with an area about $1 \%$ that of the total area of the ${ }^{19} \mathrm{~F}$ NMR spectrum). The larger bandwidth (4.12 ppm) observed in TH33 compared to the other fossil samples (2.12$3.69 \mathrm{ppm})$ is consistent with the corresponding relatively broad clumped $\left(\mathrm{CO}_{3}{ }^{2-}, \mathrm{F}^{-}\right)$defect signal observed in the infrared spectra, even though the potential occurrence of paramagnetic centres or impurities (e.g. Fe, Mn ions) in fossil bones can also affect the NMR width.

\section{Discussion}

\subsection{Evidence of secondary carbonated apatite formation in fossil bones}

The structural differences observed between fossil and modern bones, i.e. increase in crystallinity, formation of the clumped $\left(\mathrm{CO}_{3}{ }^{2-}, \mathrm{F}^{-}\right)$defect, incorporation of fluoride and hydroxyl groups suggest that dissolution of the original biogenic material and formation of secondary apatite occurred. These observations support the use of a two-phase model to interpret the properties of the $v_{1} \mathrm{PO}_{4}$ band, leading to a proportion of secondary apatite reaching $64 \%$ in the most transformed samples. Variations in the position of the $v_{1} \mathrm{PO}_{4}$ component related to secondary apatite also suggest that its composition may differ from one sample to the 
other. In F-rich fossils, i.e. TH32, TH33, MA-DB-03N, the presence of the clumped defect and the absence of structural OH signals in their ATR-FTIR spectra are in favour of secondary fluorapatite. In fossil bones with lower F content, the frequency of the second component is closer to that of hydroxyapatite $\left(\sim 963 \mathrm{~cm}^{-1}\right)$. The presence of bending and stretching bands related to structural $\mathrm{OH}$ groups also supports the formation of secondary hydroxyapatite. This is consistent with the results of bone alteration experiments (Aufort et al., 2019) indicating that formation of secondary hydroxyapatite and fluorapatite always occur, only depending on the presence or absence of fluoride, respectively. In experimental alterations, two well-defined trends are thus observed in a diagram reporting the $\mathrm{F}$ concentration as a function of the proportion of secondary phase. In the fossil samples, intermediate situations occur (Figure 4b), suggesting the formation of both secondary fluorapatite and hydroxyapatite in a single sample. The potential formation of a solid solution with a mixed fluor- and hydroxyl- composition cannot be fully excluded. However, the observation of the $\mathrm{OH}$ vibrational bands at 3572 and $630 \mathrm{~cm}^{-1}$ attests to the occurrence of extended domains of hydroxyapatite (Rodriguez-Lorenzo et al. 2003). Furthermore, even in low fluoride fossil bones, formation of carbonated fluorapatite occurred as indicated by the presence of the clumped $\left(\mathrm{CO}_{3}{ }^{2-}, \mathrm{F}^{-}\right)$defect in all fossils, even those with intense $\mathrm{OH}$ bending signals. Both observations are suggestive of the formation of individual domains of hydroxyapatite or fluorapatite, which is also consistent with the conclusions of the fluoridation experiments of dentin and enamel by Pasteris and Ding (2009).

In presence of fluorine, the formation of secondary carbonated fluorapatite is easily detected because the clumped $\left(\mathrm{CO}_{3}{ }^{2-}, \mathrm{F}^{-}\right)$defect displays a specific spectroscopic signature, both in infrared spectroscopy and ${ }^{19} \mathrm{~F}$ NMR. In the case of hydroxyapatite, the incorporation of carbonate in the secondary apatite also occurs during the experimental aqueous alteration of modern bone (Aufort et al. 2019). However, their spectroscopic signature does not significantly differ from that of the biogenic apatite. Accordingly, and even though their carbonate signal is close to that observed in biologic apatite, it is most likely that the secondary hydroxyapatite in fossil samples also contains a fraction of structural carbonates.

It is noteworthy that the highest fraction of secondary apatite observed is about $\sim 60 \%$. This limited degree of transformation does not depend on the F enrichment of the sample and is also observed in hydroxylated samples as, e.g., sample WP-DB*, which displays about $60 \%$ of secondary apatite. The highest fraction observed coincides with the maximum $\sim 60 \%$ fraction of secondary apatite determined in modern bones altered under controlled conditions (Aufort et al. 2019). Accordingly, it supports the idea that the formation of secondary apatite could have 
a protecting role against further transformation of the original bioapatite. No correlation is observed between the extent of alteration and age and even in older (e.g. TH33, TH32, WPDB) and F-rich (MA-DB-03N, TH33, TH32) samples, the transformation seems limited at about 60 percent of secondary apatite.

\subsection{Effect of the acetic acid treatment on fossil samples}

Acetic acid is the most commonly used reagent to remove exogenous carbonate from bioapatite prior to stable isotope analyses of structural carbonate and chemical analyses (Snoeck and Pellegrini 2015). It also plays a major role in fossil preparation. Indeed, extracting bones from the breccia matrix is difficult and two methods are usually used: mechanical and/or chemical preparation. The latter is more adapted to recover the microfauna and fragile fossils and, unlike mechanical preparation, does not risk leaving marks that could be misinterpreted as taphonomic or anthropic marks. For instance, the Plio-Pleistocene Palaeontology Section of the Ditsong National Museum of Natural History (Pretoria, South Africa) has developed an acid preparation lab dedicated to the extraction of fossil bones from blocks of breccia (Gommery et al. 2016). In this case, fossils are exposed to acetic acid for longer periods of time ( $\sim 24 \mathrm{~h})$ but protected using a glue coating. Effects of acetic acid on the structure and stable isotope composition of bioapatites are thus of importance to palaeoenvironmental reconstructions and have been widely discussed along with other pre-treatments (e.g. Lee-Thorp and van der Merwe, 1991; Garvie-Lok et al. 2004; Yoder and Bartelink 2010; Snoeck and Pellegrini 2015). Overall these studies show that acetic acid treatment leads to an increase in crystallinity (IRSF) and a decrease in carbonate content and partially dissolves the mineral fraction of modern and archaeological bioapatites (Snoeck and Pellegrini 2015). The present results confirm that the acetic acid treatment, even at low concentration $(0.1 \mathrm{M})$ and reaction time (30 min), besides removing the secondary calcite, affects the apatitic fraction of the samples. It leads to a moderate increase in the IRSF and overall decrease in the relative intensity of the signal of structural carbonates. It is noteworthy that the IRSF increase is similar for the whole set of samples and still allows a meaningful inter-comparison of crystallinity parameters (Figure 2). The effect of the acetic acid treatment on the $v_{1} \mathrm{PO}_{4}$ band is not detected, possibly due to the smaller intensity of this band. Based on these observations, it is suggested that the acetic acid treatment removes more soluble carbonate-rich apatitic domains, in addition to diagenetic calcite. A preferential use of acetate buffered acetic acid solutions has been recommended (e.g. Garvie-Lok et al. 2004) and leads to a smaller increase in IRSF values than unbuffered acetic 
acid (Snoeck and Pellegrini 2015) but does not completely exclude possible dissolutionrecrystallisation of bone apatite (Aufort et al. 2019).

\subsection{Implications for palaeoenvironmental reconstructions}

Regardless of the fossilisation conditions, dissolution-recrystallization of bone is systematically observed. Conditions prevailing in the environment, i.e. chemical composition of percolating fluids and possibly of the breccia in Bolt's Farm, are the main factor in driving the transformation of fossil bones. A certain homogeneity is observed within each site at Bolt's Farm, with similar $v_{2} \mathrm{CO}_{3}$ signatures for fossil bones belonging to one locality, apart from Milo A and Aves Cave I where there might be local concentration spots of fluorine, leading to further formation of secondary fluorapatite. Overall, fossil bones from the karstic environment at Bolt's Farm are less transformed in terms of percentage of secondary apatite than fossils from the fluvio-lacustrine environment (Pickford 1974) of the Tugen Hills. In karstic environments, dissolution-recrystallization also occurs but the lower F concentration of percolating solutions leads to the preferential formation of secondary hydroxyapatite. The higher solubility of hydroxyapatite compared to fluorapatite (Elliott 2002, Rakovan 2002) may explain why an overall smaller percentage of transformation is observed in Bolt's Farm fossils than in the more fluorinated fossils from the Tugen Hills. These observations confirm the sensitivity of bone to the nature of percolating solutions, making fossil bone a potential record of local physicalchemical conditions. Further works on older and different contexts are however required to confirm this suggestion. Another avenue to explore pertains to the development of a chemical treatment able to remove secondary apatite in fossils via selective dissolution of the secondary phase, giving access to the environmental and geochemical information preserved in the pristine biological apatite.

\section{Acknowledgments}

This work was supported by French state funds within the framework of the Cluster of Excellence MATISSE led by Sorbonne Universités. We We would like to thank C. Klinkert and J. Gaylord for their authorizations to conduct fieldwork on their property, R. Redelstorff and P. Hine (APM Unit, SAHRA), L. Smith (COH WHS Authority, Gauteng Provincial Government) and the French Embassy in South Africa for their continuous support. The Ditsong National Museum of Natural History, the CNRS and NRF (LIA N 1041 HOMEN) and the French Ministry of Europe and Foreign Affairs (Sous-direction de l'Enseignement supérieur et de la Recherche - Pôle Sciences Humaines et Sociales, Archéologie et Patrimoine) (MPFSA - Mission Paléoanthropologique Franco-Sud-Africaine) funded the fieldwork. The 
Kenyan samples were collected on the field by the Kenya Palaeontology Expedition funded by the CNRS (GDRI 193, UMR 7207 CR2P), the Pierre-and-Marie-Curie University (UMR 7193 ISTEP), the Muséum National d'Histoire Naturelle, the Collège French Ministry of Europe and Foreign Affairs (Commission of Archaeological Excavations). Authorizations for excavation and export were provided by the Government of Kenya (Ministry of Education, Science \& Technology). The French Région Ile de France-SESAME program is acknowledged for financial support $(700 \mathrm{MHz})$. We thank two anonymous reviewers for their thoughtful comments.

\section{References}

Aufort, J., Ségalen, L., Gervais, C., Brouder, C., Balan, E., 2016, Modeling the attenuated total reflectance infrared (ATR-FTIR) spectrum of apatite, Physics and Chemistry of Minerals, 43, 615-626.

Aufort, J., Lebon, M., Gallet, X., Ségalen, L., Gervais, C., Brouder, C., Balan, E., 2018, Macroscopic electrostatic effects in ATR-FTIR spectra of modern and archaeological bones, American Mineralogist, 103, 326-329.

Aufort, J., Gervais, C., Ségalen, L., Labourdette, N., Coelho Diogo, C., Baptiste, B., Beyssac, O., Amiot, R., Lécuyer, C., Balan, E., 2019, Atomic scale transformation of bone in controlled aqueous alteration experiments. Palaeogeography, Palaeoclimatology, Palaeoecology. https://doi.org/10.1016/j.palaeo.2019.03.042

Balan, E., Delattre, S., Roche, D., Segalen, L., Morin, G., Guillaumet, M., Blanchard, M., Lazzeri, M., Brouder, C., Salje, E.K.H., 2011, Line-broadening effects in the powder infrared spectrum of apatite, Physics and Chemistry of Minerals, 38, 111-122.

Bocherens, H., Billiou, D., Patou-Mathis, M., Bonjean, D., Otte, M., Mariotti, A., 1997, Paleobiological implications of the isotopic signatures, ${ }^{13} \mathrm{C},{ }^{15} \mathrm{~N}$, of fossil mammal collagen in Scladina Cave (Sclayn, Belgium), Quaternary Research, 48, 370-380.

Bocherens, H., Drucker, D.G., Biliou, D., Geneste, J.-M., Kezavo, B., 2008, Grotte Chauvet (Ardèche, France): A natural experiment for bone diagenesis in karstic context, Palaeogeography, Palaeoclimatology, Palaeoecology, 266, 220-226.

Elliott, J.C., 2002, Calcium phosphate biominerals. In MJ Kohn, J Rakovan, and JM Hughes, Eds., Phosphates-Geochemical, geobiological and materials importance, vol 48, p. 427-453. 
Reviews in Mineralogy and Geochemistry, Mineralogical Society of America and Geochemical society, Chantilly, Virginia.

Garvie-Lok, S.J., Varney, T.L., Katzenberg, M.A., 2004, Preparation of bone carbonate for stable isotope analysis: the effects of treatment time and acid concentration, Journal of Archaeological Science, 31, 763-776.

Gommery, D., Badenhorst, S., Potze, S., Sénégas, F., Kgasi, L., Thackeray, J.F., 2012, Preliminary results concerning the discovery of new fossiliferous sites at Bolt's farm (Cradle of Humankind, South Africa), Annals of the Distong National Museum of Natural History, 2, $33-45$.

Gommery, D., Sénégas, F., Kgasi, L., Vilakazi, N., Kuhn, B., Brink, J., Pickford, M., Herries, A.I.R., Hancox, J., Saos, T., Ségalen, L., Aufort J., Thackeray, J.F., 2016, Bolt's Farm Cave System dans le Cradle of Humankind (Afrique du Sud) : un exemple d'approche multidisciplinaire dans l'étude des sites à primates fossils, Revue de primatologie, 7, 2725.

Hedges, R.E.M., 2002, Bone diagenesis: an overview of processes, Archaeometry, 44, 319-328. Keenan, S.X., 2016, From bone to fossil: A review of the diagenesis of bioapatite, American Mineralogist, 101, 1943-1951.

Kohn, M.J. and Cerling, T.E., 2002, Stable isotope compositions of biological apatite. In Kohn MJ, Rakovan J, and Hughes JM, Eds., Phosphates - Geochemical, geobiological and materials importance, vol 48, p. 455-488. Reviews in Mineralogy and Geochemistry, Mineralogical Society of America and Geochemical Society, Chantilly, Virginia.

Kohn, M.J., Law, J.M., 2006, Stable isotope chemistry of fossil bone as a new paleoclimate indicator, Geochimica et Cosmochimica Acta, 70, 931-946.

Kolodny, Y., Luz, B., Sander, M., Clemens, W.A., 1996, Dinosaur bones: fossils or pseudomorphs? The pitfalls of physiology reconstruction from apatitic fossils, Palaeogeography, Palaeoclimatology, Palaeoecology, 126, 161-171.

Lebon, M., Zazzo, A., Reiche, I., 2014, Screening in situ bone and teeth preservation by ATRFTIR mapping, Palaeogeography, Palaeoclimatology, Palaeoecology, 416, 110-119.

Lebon, M., Reiche, I., Gallet, X., Bellot-Gurlet, L., Zazzo, A. 2016, Rapid quantification of bone collagen content by ATR-FTIR spectroscopy, Radiocarbon, 58, 131-145. 
Lee-Thorp, J.A. and van der Merwe, N.J., 1991, Aspects of the chemistry of modern and fossil biological apatites, Journal of Archaeological Science, 18, 343-354.

LeGeros, R.Z., Trautz, O.R., Klein, E., LeGeros, J.P., 1969, Two types of carbonate substitution in the apatite structure, Experimentia, 25, 5-7.

Maurer, A.F., Gerard, M., Person, A., Barrientos, I., del Carmen Ruiz, P., Darras, V., Durlet, C., Zeitoun, V., Renard, M., Faugère, B., 2011, Intra-skeletal variability in trace elemental content of Precolumbian Chupicuaro human bones: the record of post-mortem alteration and a tool for palaeodietary reconstruction, Journal of Archaeological Science, 38, 1784-1797.

Michel, V., Ildefonse, P., Morin, G., 1995, Chemical and structural changes in Cervus Elaphus tooth enamels during fossilisation (Lazaret Cave): a combined IR and XRD Rietveld analysis, Applied Geochemistry, 10, 145-159.

Michel, V., Ildefonse, P., Morin, G., 1996, Assessment of archaeological bone and dentine preservation from Lazaret Cave (Middle Pleistocene) in France. Palaeogeography, Palaeoclimatology, Palaeoecology, 126, 109-119.

Nielsen-Marsh, C.M., and Hedges, R.E.M., 2000, Patterns of diagenesis in bone I: The effect of site environments, Journal of Archaeological Science, 27, 1139-1150.

Parker, R.B., Murphy, J.W., Toots, H., 1974, Fluorine in fossilized bone and tooth: distribution among skeletal tissues, Archaeometry, 16, 98-102.

Pasteris, J.D., Wopenka, B., Valsami-Jones, E., 2008, Bone and tooth mineralization: why apatite?, Elements, 4, 97-104.

Pasteris, J.D., and Ding, D.Y., 2009, Experimental fluoridation of nanocrystalline apatite. American Mineralogist, 94, 53-63.

Pfretzschner, H.-U., 2004, Fossilization of Haversian bone in aquatic environments, Comptes Rendus Palevol, 3, 605-616.

Pickford, M., 1974, Stratigraphy and paleoecology of five late Cenozoic formations in the Kenya Rift Valley, vol1 PhD Dissertation, London University, 219p.

Pickford, M., Gommery, D., 2016, Fossil Suidae (Artiodactyla, Mammalia) from Aves Cave I and nearby sites in Bolt's Farm Palaeokarst System, South Africa, Estudios Geológicos, 72, e059:1-24. Doi : http//dx.doi.org/10.3989/egeol.42389.404. 
Rakovan, J., 2002, Growth and surface properties of apatite. In MJ Kohn, J Rakovan, and JM Hughes, Eds., Phosphates-Geochemical, geobiological and materials importance, vol 48, p. 5186. Reviews in Mineralogy and Geochemistry, Mineralogical Society of America and Geochemical society, Chantilly, Virginia.

Reiche, I., Favre-Quattropani, L., Vignaud, C., Bocherens, H., Charlet, L., Menu, M., 2003, A multi-analytical study of bone diagenesis: the Neolithic site of Bercy (Paris, France), Measurement Science and Technology, 14, 1608-1619.

Rey, C., Lian, J., Grynpas, M., Shapiro, F., Zylberberg, L., Glimcher, M.J., 1989, Non-apatitic environments in bone mineral: FT-IR detection, biological properties and changes in several disease states, Connective Tissue Research, 21, 267-273.

Roche, D., Ségalen, L., Balan, E., Delattre, S., 2010, Preservation assessment of MiocenePliocene tooth enamel from Tugen Hills (Kenyan Rift Valley) through FTIR, chemical and stable isotope analyses, Journal of Archaeological Science, 37, 1690-1699.

Roche, D., Ségalen, L., Senut, B., Pickford, M., 2013, Stable isotope analyses of tooth enamel carbonate of large herbivores from the Tugen Hills deposits: environmental context of the earliest Kenyan hominids, Earth and Planetary Science Letters, 381, 39-51.

Rodriguez-Lorenzo, L.M., Hart, J.N., Gross, K.A., 2003, Influence of fluorine in the synthesis of apatites. Synthesis of solid solutions of hydroxy-fluorapatite, Biomaterials, 24, 3777-3785.

Sawada, Y., Pickford, M., Senut, B., Itaya, T., Hyodo, M., Miura, T., Kashine, C., Chujo, T., Fujii, H., 2002. The age of Orrorin tugenensis, an early hominid from the Tugen Hills, Kenya. Comptes Rendus Palevol, 1, 293-303.

Sénégas, F., Avery, M., 1998, New evidence for the murine origins of the Otomyinae (Mammalia, Rodentia) and the age of Bolt's Farm (South Africa), South African Journal of Science, 94, 503-507.

Snoeck, C., and Pellegrini, M., 2015, Comparing bioapatite carbonate pre-treatments for isotopic measurements: Part 1 - Impact on structure and chemical composition, Chemical Geology, 417, 394-403.

Stiner, M.C., Kuhn, S.L., Surovell, T.A., Goldberg, P., Meignen, L., Weiner, S., Bar-Yosef, O., 2001, Bone preservation in Hayonim Cave (Israel): a macroscopic and mineralogical study, Journal of Archaeological Science, 28, 643-659. 
Trueman, C.N., and Martill, D.M., 2002, The long-term survival of bone: the role of bioerosion, Archaeometry, 44, 371-382.

Trueman, C.N.G., Behrensmeyer, A.K., Tuross, N., Weiner, S., 2004, Mineralogical and compositional changes in bones exposed on soil surfaces in Amboseli National Park, Kenya: diagenetic mechanisms and the role of sediment pore fluids, Journal of Archaeological Science, 31, 721-39.

Trueman, C.N.G., Behrensmeyer, A.K., Potts R., Tuross, N., 2006, High-resolution records of location and stratigraphic provenance from the rare earth element composition of fossil bones, Geochimica et Cosmochimica Acta, 70, 4343-4355.

Tuross, N., Behrensmeyer, A.K., Eanes, E.D., Fisher, L.W., are, P.E. 1989, Molecular preservation and crystallographic alterations in a weathering sequence of wildebeest bones. Applied Geochemistry, 4, 261-270.

Tütken, T., Vennemann, T.W., Pfretzschner, H.-U., 2008, Early diagenesis of bone and tooth apatite in fluvial and marine settings: Constraints from combined oxygen isotope, nitrogen and REE analysis, Palaeogeography, Palaeoclimatology, Palaeoecology, 266, 254-268.

Weiner, S., and Bar-Yosef, O., 1990, States of preservation of bones from prehistoric sites in the Near East: A survey, Journal of Archaeological Science, 17, 187-196.

Weiner, S., Goldberg, P., Bar-Yosef, O., 2002, Three dimensional distribution of minerals in the sediments of Hayonim Cave, Israel: diagenetic processes and archaeological implications, Journal of Archaeological Science, 29, 1289-1308.

Yi, H., Balan, E., Gervais, C., Segalen, L., Fayon, F., Roche, D., Person, A., Morin, G., Guillaumet, M., Blanchard, M., Lazzeri, M., Babonneau, F., 2013, A carbonate-fluoride defect model for carbonate-rich fluorapatite, American Mineralogist 98, 1066-1069.

Yi, H., Balan, E., Gervais, C., Ségalen, L., Roche, D., Person, A., Fayon, F., Morin, G., Babonneau, F., 2014, Probing atomic scale transformation of fossil dental enamel using Fourier transform infrared and nuclear resonance magnetic spectroscopy: A case study from the Tugen Hills (Rift Gregory, Kenya), Acta Biomaterialia, 10, 3952-3958.

Yoder, C.J., and Bartelink, E.J., 2010, Effects of different sample preparation methods on stable carbon and oxygen isotope values of bone apatite: a comparison of two treatment protocols, Archaeometry, 52, 115-130. 


\section{Table and Figure captions}

Table 1 - Sample description. For Bolt's Farm fossils, the first initials correspond to the name of the locality (e.g. AC for Aves Cave I), B and DB refer to breccia and decalcified breccia respectively. The asterisk refers to preliminary ages that will be further refined in later studies. Fluorine content and $\mathrm{Ca} / \mathrm{P}$ mass ratio of modern and fossil bones from Bolt's Farm and Tugen Hills. Frequency of $v_{1} \mathrm{PO}_{4}$ bands and IRSF calculated from the $v_{4} \mathrm{PO}_{4}$ band (Weiner and Bar-Yosef, 1990) in Ge ATR-FTIR spectra. The prime symbol refers to the sample after acetic acid treatment.

\begin{tabular}{|c|c|c|c|c|c|c|c|}
\hline Sample & Description & Origin & Age & $\mathrm{F}(\%)$ & $\begin{array}{l}\mathrm{Ca} / \mathrm{P} \\
\text { mass ratio }\end{array}$ & $v_{1} \mathrm{PO}_{4}\left(\mathrm{~cm}^{-1}\right)$ & $\begin{array}{l}v_{4} \mathrm{PO}_{4} \\
\text { IRSF (IRSF') }\end{array}$ \\
\hline TH1 & Modern ox bone & Bogoria Lake (Kenya) & Modern & 0.20 & 2.02 & 960.6 & 3.64 \\
\hline BPA-B & Fossil bone & Brad Pit A (BFCS, South Africa) & $4-1.5 \mathrm{Ma}^{*}$ & 0.5 & 2.36 & 962.7 & $5.35(6.19)$ \\
\hline AC-DB-5 & Fossil bone & Aves Cave I (BFCS, South Africa) & $3-2.5 \mathrm{Ma}$ & 0.6 & 2.19 & 962.5 & $4.81(5.49)$ \\
\hline $\mathrm{AC}-\mathrm{B}-\mathrm{F}$ & Fossil bone & Aves Cave I (BFCS, South Africa) & $3-2.5 \mathrm{Ma}$ & 0.8 & 2.30 & 962.9 & $4.66(5.41)$ \\
\hline WP-DB & Fossil bone & Waypoint 160 (BFCS, South Africa) & 4.5-4 Ma & 0.9 & 2.44 & 963.5 & $5.14(5.82)$ \\
\hline BC-DB-P & Fossil bone & Bridge Cave (BFCS, South Africa) & 2-0.8 $\mathrm{Ma}^{*}$ & 0.9 & 2.14 & 962.8 & $4.45(5.01)$ \\
\hline BPB-DB-25 & Fossil bone & Brad Pit B (BFCS, South Africa) & 4-3.5 $\mathrm{Ma}^{*}$ & 1.0 & 2.21 & 962.4 & $4.48(5.15)$ \\
\hline MB-DB-10 & Fossil bone & Milo B (BFCS, South Africa) & $2-1.5 \mathrm{Ma}^{*}$ & 1.1 & 2.18 & 963.4 & $4.69(5.15)$ \\
\hline BPA-DB-12D & Fossil bone & Brad Pit A (BFCS, South Africa) & 4-1.5 Ma* & 1.1 & 2.11 & 962.4 & $5.23(5.51)$ \\
\hline MA-B & Fossil bone & Milo A (BFCS, South Africa) & 2-1.5 Ma* & 1.2 & 2.21 & 963.5 & $4.44(4.99)$ \\
\hline MA-B-Cal & Fossil bone & Milo A (BFCS, South Africa) & $2-1.5 \mathrm{Ma}^{*}$ & 1.4 & 2.29 & 964.0 & $4.82(5.43)$ \\
\hline AC-DB-L & Fossil bone & Aves Cave I (BFCS, South Africa) & $3-2.5 \mathrm{Ma}$ & 1.8 & 2.16 & 963.5 & $4.98(5.20)$ \\
\hline Ma-DB-03N & Fossil bone & Milo A (BFCS, South Africa) & $2-1.5 \mathrm{Ma}^{*}$ & 2.4 & 2.15 & 965.3 & $5.72(6.12)$ \\
\hline TH33 & Fossil bone & Tugen Hills (Lukeino formation, Kenya) & $6.2-5.7 \mathrm{Ma}$ & 2.8 & 2.26 & 965.7 & 4.24 \\
\hline TH32 & Fossil bone & Tugen Hills (Lukeino formation, Kenya) & $6.2-5.7 \mathrm{Ma}$ & 2.9 & 2.21 & 965.8 & 4.69 \\
\hline C-Fap & Sedimentary Fap & Taiba (Senegal) & n.d. & 3.3 & 2.18 & 966.1 & 6.18 \\
\hline
\end{tabular}


Figure 1 - a) Diamond and b) germanium ATR-FTIR spectra of modern bone (TH1) and selected fossil bones from Bolt's Farm (MA-DB-03N and MA-B) and from the Tugen Hills (TH33). The OH bending mode is marked with an asterisk. c) Enlarged view of the $v_{2} \mathrm{CO}_{3}$ diamond ATR-FTIR band of modern bone and selected fossil bones from Bolt's Farm and the Tugen Hills. All spectra are normalised based on the $v_{4} \mathrm{PO}_{4}$ band intensity. The position of the clumped $\left(\mathrm{F}^{-}, \mathrm{CO}_{3}{ }^{2-}\right)$ defect is indicated by a vertical dashed line. d) Enlarged view of the $v_{1} \mathrm{PO}_{4}$ Ge ATR-FTIR band (black), Gaussian (orange) and Lorentzian (green) components of the fits (see text) of the $v_{1} \mathrm{PO}_{4} \mathrm{Ge}$ ATR-FTIR band (red), in modern bone and selected fossil bones from Bolt's farm and the Tugen Hills.
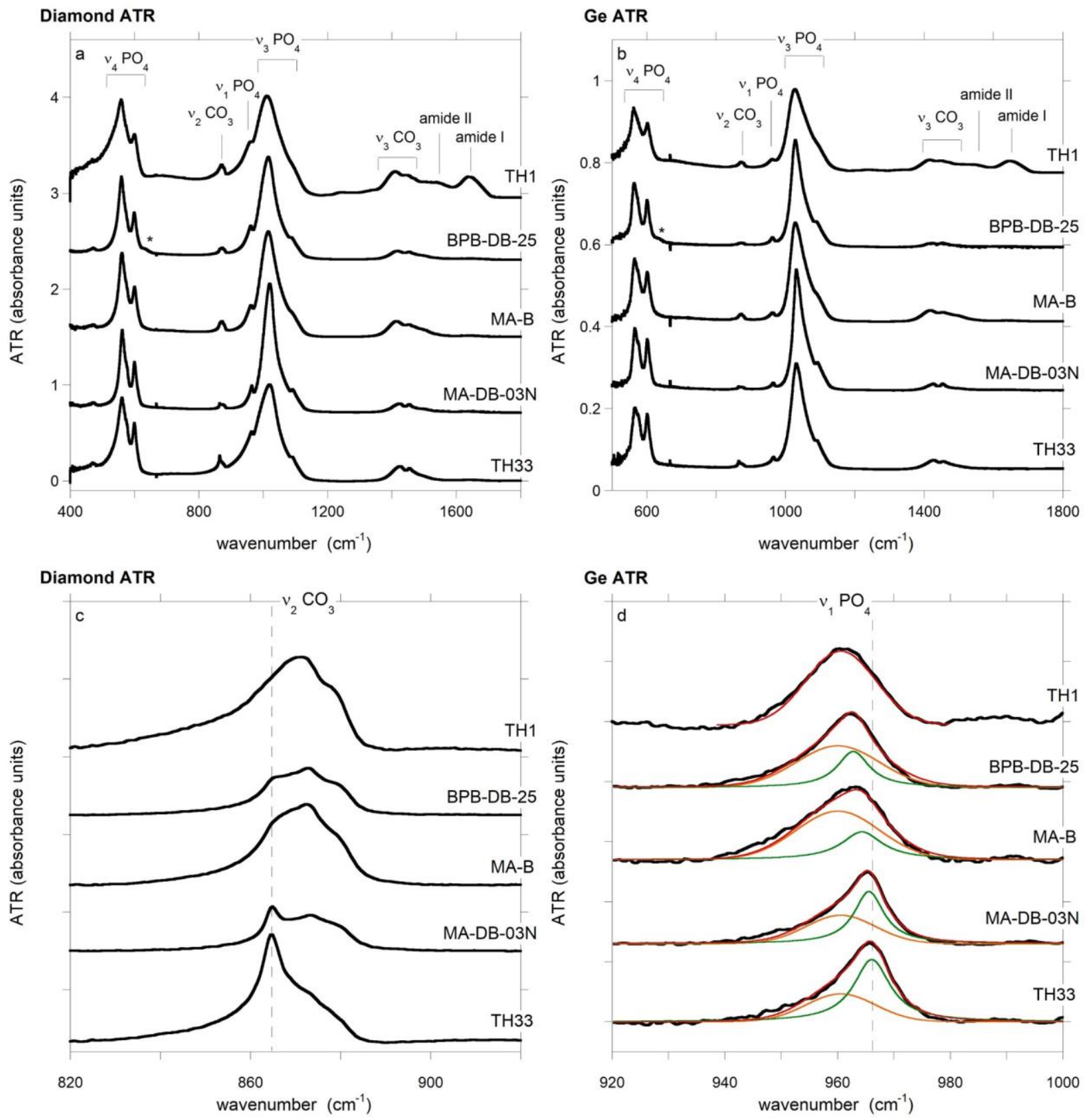
Figure 2 - a. $v_{4} \mathrm{PO}_{4}$ germanium ATR-FTIR bands of a calcite-containing (WP-DB) and calcite-free (AC-DB-L) fossil bone samples before (red) and after acetic acid (black) treatment. b. IRSF values calculated from Ge ATR-FTIR spectra for modern bone and sedimentary carbonated fluorapatite (diamonds) and for Bolt's Farm fossil bones before (red circles) and after (open black circles) acetic acid treatment.
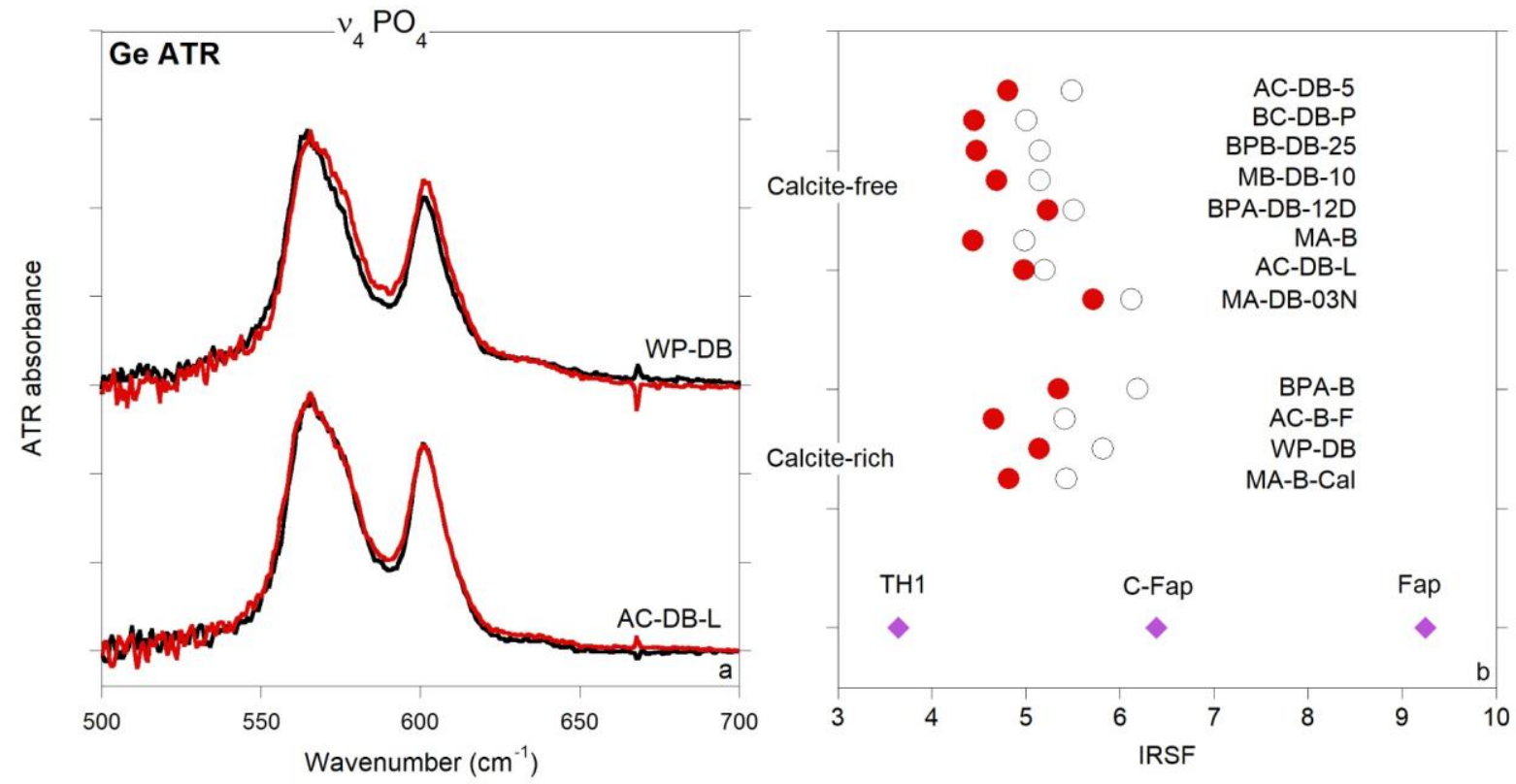
Figure $3{ }^{19} \mathrm{~F}$ MAS NMR spectra of BPB-DB-25 and MA-D-03N fossil bone samples from Bolt's Farm and TH33 from the Tugen Hills compared to that of sedimentary carbonated fluorapatite. The ${ }^{19} \mathrm{~F}$ position of the clumped defect is indicated by a vertical dashed line.

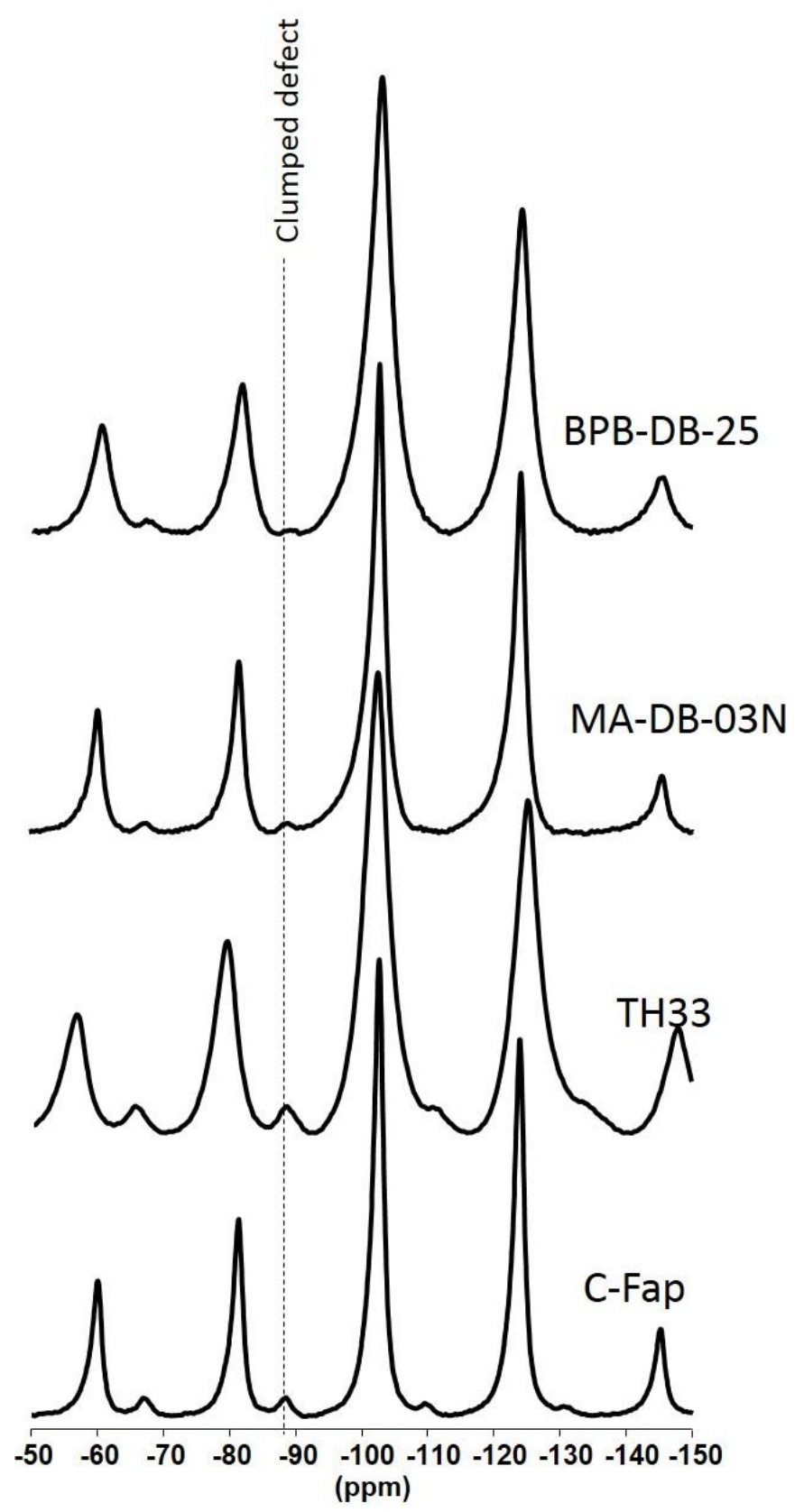


Figure $4-\mathbf{a}$. Evolution of the fluorine content as a function of the position of the $v_{1} \mathrm{PO}_{4} \mathrm{Ge}$ ATR-FTIR band. b. Evolution of fluoride content as a function of the percentage of secondary apatite in Bolt's Farm and Tugen Hills fossils. The fraction of secondary apatite is proportional to the relative area of the Lorentzian component of the $v_{1} \mathrm{PO}_{4}$ Ge ATR-FTIR band fit (see text). Dashed lines are guide for the eye. Note the maximum degree of transformation at $\sim 60 \%$ and the samples plotted below the linear mixing trend between biogenic and fluor-apatite, attesting to the formation of secondary hydroxyapatite.
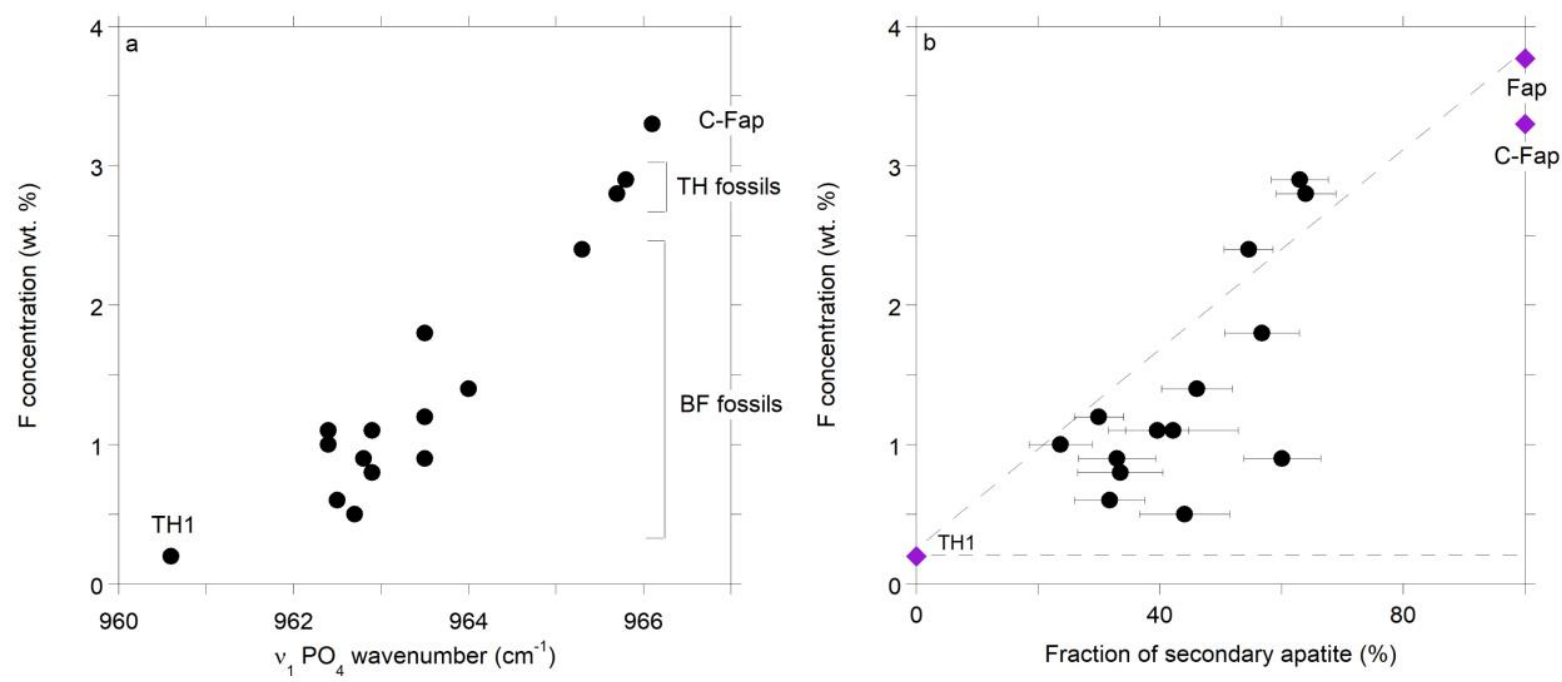